Iryna Izhutova (2019) Ukrainian Strategic Communications and martial law. Social development \& Security. 9(5), 127 - 132. DOI: http://doi.org/10.33445/sds.2019.9.5.8

\title{
Ukrainian Strategic Communications and martial law
}

\section{Iryna Izhutova}

The National University Defence of Ukraine named after Ivan Chernyakhovsky, 28, Povitroflotsky Ave, Kyiv-049, 03049, Ukraine, e-mail: perevod_vu@ukr.net, Chief of Training Section, Education and Research Centre for Strategic Communications in Security and Defence Sector.

\begin{tabular}{|c|c|}
\hline Pen ACcess & $\begin{array}{l}\text { Abstract: } \text { This article aims at researching the implementation } \\
\text { of strategic communications within the introduction of the martial }\end{array}$ \\
\hline Article h & ed the consolidation, coordination, ar \\
\hline & jectives and goals. \\
\hline October, 2019 & strategic communications, \\
\hline
\end{tabular}
communications, target audiences, fakes.

\section{Problem statement}

\subsection{Research novelty}

Following the open armed aggression of Russian Federation on November 25 2018 in the Kerch Strait against a group of the Ukrainian Navy vessels, based on the proposal of the National Security and Defence Council of Ukraine and in line with par. 20, art. 106, Constitution of Ukraine, Law of Ukraine On Martial Law the President of Ukraine signed the Decree No. 393/2018 about introduction of the martial law in Vinnytsia, Luhansk, Donetsk, Zaporizhia, Mykolaiv, Odesa, Sumy, Kharkiv, Chernihiv, Kherson oblasts, as well as in domestic waters of the Azov-Kerch water zone for 30 days [1].

The concept of the strategic communications officially appeared in Ukraine in 2015 when the National Security and Defence Council and NATO International Secretariat signed the Roadmap of Strategic Communications Partnership to develop the Ukrainian capability to realize effective communications, as well as form sustainable internal and government/interdepartmental system of strategic communications [2].

The events in Ukraine proved the necessity to improve the national communication strategy and establish cooperation of all participants of the communication process.

\subsection{Recent research and publications analysis}

The issue of strategic communications in the interests of the national security and defence has been considered in studies of G.Pocheptsov, D.Dubov, A.Barovska, O.Kushnir, V.Lipkan, I.Panteleichuk, etc., meanwhile, these communications, media cooperation, public affairs during the introduction of the martial law has not been 
analyzed. Unfortunately, there is no any common understanding of the integrity of strategic communications system at the national level for now, especially, in the context of the Russian aggression against Ukraine, as well as dynamic development of information technologies and media space.

Based on the conducted analysis, certain problems, which are related to the absence of the comprehensive policy of strategic communications (despite some legislative documents fixing the "strategic communications" term) and strict structure of strategic communications in Ukraine, were defined; this problem is obvious in terms of cooperation with population. In case of crisis the interdepartmental cooperation and necessity of appropriate and immediate response to problems considering speed of messages spreading in current digital media space are also important.

The after-action review system, especially, the crisis response system (crisis communications), which is aimed at correcting errors and their avoiding, remedial actions and work improvement, are not well-developed, too. However, "Russian Federation aggression against Ukraine, especially information aggression, forced the national security and defence experts to search possible mechanisms of the comprehensive response to this challenge. In this case the response search features are limited by the necessity to consider the democratic system of the Ukrainian state and implement the concepts of freedom of speech, absence of obligatory ideology and other achievements of the democratic society" [3].

\subsection{Problem definition}

The observation of the mentioned events in Ukraine resulted in formation of the aim of this article such as to research the strategic communications during introduction of the martial law in Ukraine.

\section{Statement of basic materials}

2.1. The Doctrine of Information Security approved by the Presidential Decree of Ukraine on February 252017 No. 47/2017, strategic communications mean coordinated and appropriate use of communicative capabilities of the state such as public diplomacy, public affairs, information and psychological operations, and activities aimed at promoting the state goals;

government communications mean a range of activities anticipating the dialog of authorized representatives of the Cabinet of Ministers of Ukraine with target audience in order to clarify the government position and/or policy in problematic issues;

crisis communications mean a range of activities realized by state authorities of Ukraine in crisis situation anticipating their dialog with target audience in terms of issues related to crisis situation; and strategic narrative means a specially prepared text designed for verbal presentation during strategic communications in order to use information influence on target audience [4].

The mentioned doctrine defines the tasks for ministries and services. Thus, the Ministry of Defence of Ukraine should ensure functioning the system of civil-military cooperation at places of permanent stationing and deployment of the Ukrainian Armed Forces units, other armed formations, as well as organize and ensure:

Relations with Ukrainian and foreign media representatives to cover the situation 
in the region of the anti-terror operation in Donetsk and Luhansk oblasts;

Response to special information operations against the Armed Forces of Ukraine and other military formations;

Providing information tools for defence of Ukraine tasks accomplishment; and

Inform service members of the Armed Forces of Ukraine, other military formations, especially, through the representatives of media of the Armed Forces of Ukraine [4].

2.2. The introduction of martial law in some regions of Ukraine required intensification of implementation of strategic communications techniques at different national levels and outside the state.

The role of basic elements of strategic communications such as public diplomacy, public affairs, crisis communications, and military public affairs showed up the most important at this particular time. We think their use was expressly observed during the martial law period.

On November 26, 2018 a joint briefing of the Ukrainian Navy Commander and Minister of the Foreign Affairs Ministry of Ukraine was held; its topic was to speak about the ongoing situation in the Sea of Azov.

The Ministry of Foreign Affairs, Ministry of Information Policy, and Ministry of Defence of Ukraine coordinated their actions within the framework of the "Yedynyi Golos" (Single Voice) government communications strategy, which aimed at spreading maximum information from executive authorities in different forms (infographics, presentations, comments, press releases, etc.).

Further, Deputy Minister of Information Policy stressed that was the first time Ukraine executed communications in such a crisis as martial law, and he also underscored that the government communications offices had huge experience in crisis communications gained since beginning of Russian aggression in the east of Ukraine [5].

Simultaneously, both head of state and Minister of Defence held a range of meetings with representatives of foreign states in Ukraine and foreign organizations while clarifying the legal basis of the martial law [6 - 7].

2.3. In response the aggressor state intensified information warfare; after the introduction of the martial law fake messages saturated the information space of Ukraine:

- mailout on behalf of the Ministry of Defence of Ukraine of SMS to citizens of the border regions of Ukraine requiring to arrive to military commissariats and in case of refuse to do it an action will be brought against this person;

- fake order of the Minister of Defence about confiscation of vehicles with foreign registration in favour of the Ministry of Defence;

- distribution of messages in Viber about recording of all messages and calls with reference to the "federal" government;

- active imposing of an opinion through social media that the martial law was introduced forever;

- information that men in two eastern regions of Poland bordering with Ukraine receive messages from the Polish State Security Centre to come to military units because of events in Ukraine [8].

The aim of all these actions was to spread panic and increase the level of anxiety 
and agitation among population. According to the Security Service of Ukraine, a particular network, where internet provocateurs spread similar information, including fake images, for example, empty shop shelves images, was formed in country [9].

The aggressor state consolidated its propaganda efforts spreading traditional narratives against Ukraine, for example about splitting of the Ukrainians in two categories, which was followed by the misinformation that the martial law was introduced in those regions where people had not allegedly supported the president in 2014 elections. A language issue was also showed up; it concerned the alleged violation of rights of Russian speaking citizens; it was also stressed the postponing the presidential elections, strengthening the dictatorship and increasing the provocations in country, reducing the Ukrainian currency rate and panic among population, which allegedly bought out food products, matches and other products being afraid of economic crisis [10]. Social media were saturated with posts appealing to oppose martial law, some posts were reposted 12,000 times per hour (especially, a post of allegedly service member who reassured everyone that this martial law had been introduced for a long period) [11]. Followers spread this message automatically without checking information in the reliable source. This is the result of lack of cooperation with people (target audiences), uncertainty and absence of analysis of communication with citizens. The government fought with these manifestations by providing information supported by facts, fixing by these actions one of the main principles of the European state - do not answer to propaganda and disinformation by propaganda but provide only facts.

2.4. In the existing conditions it was necessary to respond immediately to the situation, rebut disinformation spreading maximally true messages in all the media and social media, activate public diplomacy by informing the communities outside Ukraine, all ministries and services had to work in a coordinated manner in Ukraine to prevent information campaigns against the Ukrainian state by joint briefings, press conferences, providing comments from authorized persons.

The immediate response of Ukraine to the incident in the Kerch Strait and organization of public diplomacy events received the reaction at the international level. Thus, the extraordinary meeting of the Ukraine - NATO Commission was convened followed by the statement of Secretary General Jens Stoltenberg about the full support of Ukraine from the NATO nations [12].

2.5. "Ukraine-2020" Strategy of Sustainable Development approved by the Presidential Decree of Ukraine dd January 12, 2015 No. 5/2015 prioritizes the reform of national security and defence system such as establishment of effective state system of crisis response (network of situation centres of central executive authorities) [13]. Considering this document, the Ministry of Defence of Ukraine deployed a situational centre consisting of representatives of all defence structures. During the martial law introduction, the first level operational reserve underwent training; problematic issues related to interaction among state executive authorities etc, were specified; moreover, government communications were also activated.

\section{Conclusions and prospects of further researches}

The article analyzes the realization of strategic communications as current form 
of expression and presentation of own interests at national and international levels under the martial law, as well as in the context of hybrid threats for Ukrainian and outside it. Although building strategic communications capabilities, in particular in the security and defence sector, has just started, it is realized in a crisis and imperfection of the whole system, which requires a clearer definition, structuring and delimitation of tasks; meanwhile, the communications were effective and achieved the primary tasks such as spreading true information, facts, contributed to realization of national interests, prevented the spread of panic and rooted propaganda.

State authorities could respond immediately to crisis by integrated evaluation of information threats; it means the raise of national capability to respond to real and potential information threats to national interests in line with national strategy and policy of Ukraine and keeping confidence in security and defence sector and state.

Currently, it is important to define the strategic narrative which will be implemented at all the levels (from strategic to tactical) considering different audiences.

\section{References}

1. Ukaz Prezy`denta Ukrayiny` Pro vvedennya voyennogo stanu v Ukrayini \# 393/2018 vid 26 ly`stopada 2018 roku. URL: https://www.president.gov.ua/documents/3932018-25594. [In Ukrainian]

2. Dorozhnya karta Partnerstva u sferi strategichny`x komunikacij mizh Radoyu nacional`noyi bezpeky` i oborony` Ukrayiny` ta Mizhnarodny`m sekretariatom NATO. URL: https://mfa.gov.ua/mediafiles /sites/nato/files/Roadmap_Ukr.pdf. [In Ukrainian]

3. Dubov D. V. Strategichni komunikaciyi: problemy` konceptualizaciyi ta prakty`chnoyi realizaciyi // Strategichni priory`tety`. Seriya: Polity`ka. 2016. \# 4. p. 9 - 23. URL: http://nbuv.gov.ua/ UJRN/sppol_2016_4_4. [In Ukrainian]

4. Ukaz Prezy`denta Ukrayiny` Pro rishennya Rady` nacional noyi bezpeky` i oborony`Ukrayiny` vid 29 grudnya 2016 roku "Pro Doktry`nu informacijnoyi bezpeky` Ukrayiny"” \# 47/2017 vid 25 lyutogo 2017 roku. URL: https://www.president.gov.ua/documents/472017-21374. [In Ukrainian]

5. Departament informaciyi ta komunikacij z gromads`kistyu Sekretariatu Kabinetu Ministriv Ukrayiny' "U ramkax \#Yedy'nogogolosu obgovoreno kry’zovi komunikaciyi v umovax voyennogo stanu". URL: https://www.kmu.gov.ua/ua/news/u-ramkah-yedinogogolosuobgovoreno-krizovi-komunikaciyi-v-umovah-voyennogo-stanu. [In Ukrainian]

6. Ministr oborony` Ukrayiny` proviv zustrich z Poslom Spolucheny`x Shtativ Amery`ky`v Ukrayini. URL: $\quad$ http://www.mil.gov.ua/news/2018/11/27/ministr-oboroni-ukraini-proviv-zustrich-zposlom-spoluchenih-shtativ-ameriki-v-ukraini/?fbclid=IwAR0FHWNzMLkvZ_8Bank8RjAUVoL_ztjtCJEPHiWqRTCoOsRUDMweBpZpVA. [In Ukrainian]

7. Prezy`dent zakly`kav svit do yednosti ta solidarnosti z Ukrayinoyu: interv'yu telekanalu CNN. URL: https://www.president. gov.ua/news/prezident-zaklikav-svit-do-yednosti-ta-solidar nosti-z-ukrayi-51438. [In Ukrainian]

8. Syuzhet TSN.ua Pol`s`ky`m cholovikam pochaly` masovo pry`xody`ty' fejkovi SMS pro mobilizaciyu $\mathrm{v}$ krayini. URL: https://tsn.ua/svit/polskim-cholovikam-pochali-masovoprihoditi-feykovi-sms-pro-mobilizaciyu-krayini-1257015.html. [In Ukrainian]

9. SBU vy`kry`la merezhu Internet-provokatoriv, najnyaty`x speczsluzhbamy`RF dlya poshy`rennya paniky` v krayini pislya vvedennya voyennogo stanu: video. URL: https://ssu.gov.ua/ ua/news/1/category/ 21/view/5490\#.8zOjTuUt.dpbs. [In Ukrainian]

10. Kevorkyan K. Nemnozhechko voennogo polozheny`ya. Pervee sutky`v novom statuse . URL: 
https://rusvesna.su/news/1543515205. [In Russian]

11. Post blogera Andriya Ganusa $\mathrm{u}$ social'nij merezhi Facebook URL: https://www.facebook.com/photo.php?fbid=2018450131571809\&set=a.843597555723745 \&type $=3 \&$ theater. [In Russian]

12. Press conference by NATO Secretary General Jens Stoltenberg following the meeting of the NATO-Ukraine Commission. URL: https://www.nato.int/cps/en/natohq/opinions_ 160789.htm.

13. Ukaz Prezy`denta Ukrayiny` pro Strategiyu stalogo rozvy`tku “Ukrayina - 2020” \# 5/2015 vid 12 sichnya 2015. URL: https://zakon. rada.gov.ua/laws/show/5/2015. [In Ukrainian] 